Utah State University

DigitalCommons@USU

Co

Bee Lab

3-1-1869

\title{
A list of the North American species of the genus Anthophora, with descriptions of new species
}

Ezra Townsend Cresson

Follow this and additional works at: https://digitalcommons.usu.edu/bee_lab_co

Part of the Entomology Commons

\section{Recommended Citation}

Cresson, Ezra Townsend, "A list of the North American species of the genus Anthophora, with descriptions of new species" (1869). Co. Paper 393.

https://digitalcommons.usu.edu/bee_lab_co/393

This Article is brought to you for free and open access by the Bee Lab at DigitalCommons@USU. It has been accepted for inclusion in Co by an authorized administrator of DigitalCommons@USU. For more information, please contact digitalcommons@usu.edu.

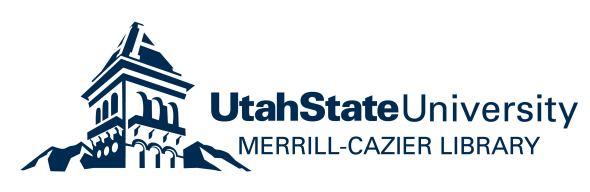




\section{A list of the North American species of the genus ANTHOPHORA, with descriptions of new species.}

BY E. T. CRESSON.

The species known to me may be recognized by the aid of the following table:

Abdomen with white marginal fasciæ:

Thorax and base of abdomen with ochraceous pubescence:

Terminal joint of middle tarsi of $\}$ eiliated laterally; clypeus with two black spots at base ...................................................Walshii, $\delta$.

Terminal joint of middle tarsi of $\delta$ simple; elypeus with only a short black line on lateral suture. Smithii, $\hat{\delta}$ ㅇ.

Terminal joint of middle tarsi of $\delta$ simple; hind legs swollen and basal joint of their tarsi toothed within. californica, $\delta$.

Thorax and base of abdomen with sooty, or mixed black and white, pubescence. marginata, + .

Abdomen subfasciate with pale pubescence:

Thorax and base of abdomen with dense ochraceous pubescence....montana, $q$.

Thorax and abdomen with thin pale or yellowish pubescence, tip of abdomen with fulvous pubescence; basal joint of hind tarsi simple..terminalis, $\hat{\sigma} q$. Abdomen not fasciate:

Thorax and first segment of abdomen with a hoary pubescence, middle tarsi long, eiliated with fulvous, and terminal joint with black pubeseence; basal joint of hind tarsi simple....

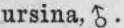

Thorax and first segment of abdomen with a dense ochraceous pubescence; rest of abdomen shining, almost nude; first recurrent nervure entering second submarginal cell at tip. floridana, $q$.

Thorax and first segment of abdomen, more or less, with a pale ochraceous pubescence; rest of abdomen dull, with short black pubescence; first recurrent nervure entering second submarginal cell in middle; basal joint of hind tarsi of $\hat{\delta}$ with a blunt tooth within abrupta, $\hat{\delta}$ ㅇ.

Thorax, and first and base of second segments of abdomen with lemon-yellow pubescence; vertex and occiput with black pubescence; basal joint of hind tarsi of $\delta$ toothed within ...................................eanadensis, $\delta$.

Thorax, and the first and second, and sometimes the third segments of abdomen with whitish pubescence; the basal joint of hind tarsi of $\delta$ toothed within.............................................................bomboides, $\delta$.

Entire body covered with a short, dense, bright yellow pubescence; basal joint of hind tarsi of $\delta$ toothed within............................ocidentalis, $\delta$.

Pubescence of body black, except apex of thorax and base of abdomen where it is bright ferruginous; basal joint of hind tarsi $(\delta)$ simple...tricolor, $\delta$.

Pubescence of the body entirely black; basal joint of the posterior tarsi $(\hat{\delta})$ simple. atrata, $\delta$.

1. Anthophora Smithii, n. sp.

s ․-Form short and very robust; black, opaque; head, thorax, legs and first abdominal segment clothed with short, dense, pale yellowish pubescence, that on the thorax beneath hoary; apical margin of TRANS. AMER. ENT. SOC. MARCH, 1889. 
all the abdominal segments above, except the last, and in the $\delta$ the clypeus, the space on each side, labrum, spot on mandibles and scape in front, white; on each side of the clypeus there is a short sutural black line, and the labrum has a black dot on each side above. Wings hyaline, apical margin faintly dusky; basal joint of posterior tarsi of $\hat{\sigma}$ simple. Length $6-6 \frac{1}{2}$ lines.

Hab.-Colorado, (Mr. J. Ridings); Dacota Territory (Mr. Henry Ulke). (Coll. Am. Ent. Soc.) This fine species is dedicated to Frederick Smith, Esq., of the British Museum, the distinguished hymenopterist.

\section{Anthophora Walshii, n. sp.}

$\hat{\delta}$ ㅇ.-Differs from Smithii as follows:-The clypeus of the $\delta$ has two black spots at base, and the apical joint of the intermediate tarsi is ciliated laterally with black pubescence, giving the joint a dilated appearance; base of claws ferruginous; basal joint of posterior tarsi of o simple. Length $6-6 \frac{1}{2}$ lines.

Hab.-Illinois, (Coll. Am. Ent. Soc.).

Although the $\delta$ of this species presents characters by which it can at once be distinguished from that of Smithii, yet the only perceptible difference between the other sex is the greater breadth of the abdomen of Wulshii. Dedicated to Benj. D. Walsh, Esq., to whom the Society is indebted for a fine series of this elegant species.

\section{Anthophora marginata.}

Anthophora marginata, Smith, Brit. Mus. Cat. Hym. ii, p. 339.

Hab.-Orizaba, Mexico. (Coll. Am. Ent Soc. from Prof. F. Sumichrast.) Three $q$ specimens.

\section{Anthophora californica, n. sp.}

o.-Black; head, thorax, legs and basal segment of abdomen with dense ochraceous pubescence, short on the legs; clypeus, space on each side, transverse line above, large spot on mandibles, scape in front, and narrow apical margin of abdominal segments above, whitish or yellowish; wings hyaline, faintly dusky at apex ; posterior legs very robust, apex of their tibiæ with a stout, blunt spine within, and basal joint of their tarsi dilated, with a long flattened process within. Length 5 lines.

Hab.-California. (Coll. Am. Ent. Soc., from Baron R. Osten Sacken.)

5. Anthophora montana, n. sp.

․- -Robust, black ; sides of face, labrum, vertex, cheeks and occiput, clothed with a short, dense, pale ochraceous pubescence, slightly 
mixed with black on the vertex; face and clypeus closely punctured; mandibles black, polished, fulvous before apex, beneath with a fringe of long whitish pubescence; thorax and first segment of abdomen above, clothed with a short and very dense yellowish pubescence, the pleura with less dense ochraceous pubescence; wings subhyaline, apical margin broadly dusky; legs black, outer side of tibiæ clothed with ochraceous pubescence, base of claws fulvous; apex of abdominal segments above, with a more or less distinct band of very short, pale ochraceous pile, more obvious in certain lights; tip of fifth segment with dense black pubescence; extreme sides of apical segments with whitish pubescence, also tufts of same on sides of apical ventral segments. Length $6 \frac{1}{2}-7$ lines.

Habitat.-Colorado, (Coll. Am. Ent. Soc., collected by Mr. James Ridings).

\section{Anthophora floridana.}

Anthophora floridana, Smith, Brit. Mus. Cat. Hym. ii, p. 339, 合 $q$.

Hab.- "Florida" (Smith); Penn. Ills. (Coll. Am. Ent. Soc. o ).

\section{Anthophora abrupta.}

Anthophora abrupta, Say, Bost. Jour. Nat. Hist. i, p. 409. $\delta$.

Anthophora sponsa, Smith, Brit. Mus. Cat. Hym. ii, p. 339. $q$.

Hab.-Mass., W. Va., Ills. (Coll. Am. Ent. Soc.). The basal segment of abdomen is sometimes entirely black.

\section{Anthophora ursina, n. sp.}

\$.-Robust, black; sides of face, vertex, cheeks, thorax, anterior femora beneath, and base of abdomen, clothed with a rather dense, long whitish pubescence; remainder of abdomen shining, with very short black pubescence; apex of clypeus, a triangular mark on each side, labrum, except two dots at base, and the scape in front, lemon-yellow; remainder of antennæ black ; wings hyaline; middle joints of tarsi fulvous; intermediate tarsi long and slender, ciliated with long fulvous pubescence, base of first joint and the terminal joint black, the latter ciliated laterally with black pubescence, as in $\hat{\delta}$ of Walshii ; basal joint of posterior tarsi long and simple. Length $6 \frac{3}{4}$ lines.

Hab.-West Virginia. (Ridings, Coll. Am. Ent. Soc.) A very distinct species.

\section{Anthophora bomboides.}

Anthophora bomboides, Kirby, Faun. Bor. Am. iv, p. 271, $\delta$.

Hab.-Mass., Conn., Penn., W. Va. (Coll. Am. Ent. Soc.). In the $q$, the pubescence of the head, except a slight mixture of pale hairs, and also a spot on the disk of the thorax, is black; the first and second abdominal segments always, and sometimes more or less of the third 
segment, are elothed with short ochraceous pubescence; the remainder is black or brownish; the venter of $\hat{\delta}$ has sometimes a scattered pale pubescence; and the basal joint of the posterior tarsi is dilated and toothed within. Length $6-6 \frac{1}{4}$ lines.

10. Anthophora canadensis, n. sp.

o.-Much like bomboides, but differs by the pubescence of the thorax, and first and base of second abdominal segments above, being lemon-yellow; the pubescence of the vertex, occiput and cheeks is black. Length $5 \frac{3}{4}$ lines.

Hab.-Ontario, Canada, (J. Pettit, Esq., Coll. Am. Ent. Soc.).

11. Anthophora occidentalis, n. sp.

9.-Black; body clothed with a short, dense, yellow pubeseence, shortest on abdomen, tip of latter dusky; legs with ochraceous pubescence; wings hyaline, apex dusky. Length $7 \frac{3}{4}$ lines.

$\}$.-Clypeus, face on each side, labrum, except two black spots at base, spot on base of mandibles, and scape in front, lemon-yellow; most of tarsi fulvo-testaceous, basal joint of posterior pair acutely toothed within; tip of abdomen scarcely dusky; otherwise like the $\$$.

Hab.-Colorado, (Ridings, Coll. Am. Ent. Soc.).

12. Anthophora terminalis, n. sp.

९.-Form short and robust, black, shining; face, thorax and hind tibiæ densely, and abdomen sparsely clothed with a pale ochraceous pubescence; vertex and disc of thorax with black pubescence; two apical segments of abdomen with bright fulvous pubescence; second, third and fourth segments with an apical fringe of pale ochraceous pubescence, more or less interrupted medially; apex of tarsi fulvous; head and thorax elosely punctured, abdomen indistinctly so; wings subhyaline, apical margin faintly dusky. Length $5 \frac{1}{2}$ lines.

$\hat{\delta}$.- L Less robust, with longer pubescence, which is rather hoary; clypeus, a spot on each side, and the labrum, yellow ; basal joint of posterior tarsi long and simple; abdominal fasciæ entire; two apical segments with short black pubescence; terminal segment deeply emarginate, and on each side of venter a tuft of whitish pubescence. Length 5 lines.

Hab.-Canada, Mass., Conn., Del., and Colorado, (Coll. Am. Ent. Soc.). Sometimes the pubescence is quite yellow, but generally very pale ochraceous.

\section{Anthophora tricolor.}

Anthophora tricolor, St.Farg. Hym. ii, p. 86$\}$.

Hab.- "Guadaloupe," (St.F.); Hayti, (Uhler, Coll. Am. Ent. Soc.) 
14. Anthophora atrata.

Anthophora atrata, Cresson, Proc. Ent. Soc. Phil. iv, p. 189, §.

Hab.-Cuba, (Coll. Am. Ent. Soc.).

Species not recognized.

Anthophora frontata, Say, Bost. Jour. Nat. Hist. i, p. 409.

Hab.- "Louisiana." Near to abrupta, Say.

Anthophora fuscipennis, Smith, Brit. Mus. Cat. Hym. ii, p. 338.

Hab._- "North America." Allied to atrata, Cresson.

Anthophora domingensis, St.Farg. Hym. ii, p. 32.

Hab.- "St. Domingo."

Anthophora taurea, Say, belongs to the genus Melissodes, a list of the species of which is now in preparation.

\section{Notes on CUBAN HYMENOPTERA, with descriptions of new species.} BY E. T. CRESSON,

Sphex mandibularis, n, sp.

․-Deep black; broad anterior orbits, cheeks, pectus, narrow posterior margin of prothorax, three lines on mesothorax (the lateral ones confluent behind), tubercles, spot behind, stripe above each of the four posterior coxæ, and the post-scutellum, bright silvery; head thinly clothed with long black pubescence, whitish on the cheeks; mandibles flavo-testaceous, apical half black; pleura and metathorax with long, thin, whitish pubescence; sides of metathorax and coxæ with silvery pile, more obvious in certain lights; metathorax opaque, rounded above and behind, the surface not distinctly sculptured; tegulæ shining-black; wings smoky hyaline, with a brilliant violet reflection, apical margin broadly fuliginous; legs black, coxæ and femora with a changeable silvery pile; posterior tibiæ golden sericeous within; abdomen black, immaculate, smooth and polished. Length $11 \frac{1}{2}$ lines

One specimen. (No. 531, Coll. Dr. J. Gundlach).

Larrada luteipennis, n. sp.

o. - Black, opaque, varied with a very fine changeable silvery pile, more obvious on face, sides and apex of metathorax and on abdomen; vertex with two broad, shallow, longitudinal impressions; antennæ nearly as long as head and thorax; metathorax finely sculptured, verge of posterior truncation carinate; tegulæ testaceous; wings yellow, apical half fuliginous; legs black, varied with silvery pile, spines whitish; abdomen short, ovate, first three segments above with a slightly interrupted silvery band at apex, apical segment also silvery. Length 4 lines.

Two specimens. (Coll. Am. Ent. Soc. and Dr. J. Gundlach.) 


\section{Monedula insularis.}

Monedula insularis, Dahlb. Hym. Eur, i, p. 186, $\subsetneq$. Cresson, Proc. Ent. Soe. Phil. iv, p. 143, $\delta$.

In addition to the markings enumerated in description of normal $q$ (1. c. p. 143), there is a transverse yellow mark, sometimes slightly interrupted in the centre, on posterior margin of mesothorax, immediately before the scutellum, and the two lines on the mesothorax are sometimes longer, broader and more distinct. In Var. $q$, some specimens have two small, oblique yellow spots on posterior face of metathorax, the longitudinal lines of mesothorax wanting, and the metathorax immaculate except a reniform mark on each extreme side.

\section{Bembex argentifrons.}

Bembex argentifrons, Cresson, Proc. Ent. Soc. Phil. iv, p. 141, $\delta$ $\$$.

The $q$ varies much in size, from $4 \frac{1}{2}$ to 6 lines long; the two short lines on mesothorax are wanting, the emargination of abdominal fasciæ more or less obsolete; venter sometimes with more black than yellow. The $\delta$ is quite constant in coloration and style of ornamentation, the bands of the abdomen, however, are often without any green stains.

\section{Bembex armata.}

Bembex armata, Cresson, Proc. Ent. Soc. Phil, iv, p. 142, 合

The $\delta$ has the clypeus sometimes bright yellow; the pile on the tho$\operatorname{rax}$ is sometimes so dense as almost to cover the markings, especially those of the mesothorax.

\section{Odynerus dejectus.}

Odynerus dejectus, Cresson, Proc. Ent. Soc. Phil. iv, p. 164, $\subsetneq$.

$\{$.-Clypeus, mandibles, scape of antennæ, spot on each side of metathorax just behind postscutellum, four anterior femora, all the tibiæ, and spot on four posterior coxæ beneath, lemon yellow; tarsi yellowish-fulvous; fifth and sixth dorsal segments of abdomen have each a short, apical, yellow fascia. Antennæ subclavate, hooked at tip; otherwise like the $q$. Length 3 lines.

One specimen. (Coll. Dr. J. Gundlach.)

\section{Odynerus cingulatus.}

Odynerus cingulatus, Cresson, Proc. Ent. Soc. Phil. iv, p. 162, 9 .

今.-Pubescent; head slightly broader than thorax; clypeus subemarginate at tip; flagellum of antennæ fulvous beneath, apex hooked; anterior angles of prothorax prominent; otherwise like the $q$. Length $3 \frac{3}{4}$ lines.

Two specimens. (Coll. Am. Ent. Soc. and Dr. J. Gundlach, No. 216.)

\section{Odynerus cubensis.}

Odynerus cubensis, Cresson, Proc. Ent. Soc. Phil. iv, p. 156, $q$.

o.-Fusco-ferruginous, covered with a rather dense, short, subser- 
iceous, yellowish pubescence; tip of antennæ hooked and acute ; metathorax with a large yellow spot on each side at base; pleura and metathorax silvery; second segment of abdomen with a short, transverse, sometimes uneven, line on each side, instead of a band as in $q$; beneath, the second segment has a large reniform mark at tip, sometimes with a median fuscous spot; otherwise as in $q$. Length 6 lines.

Two specimens. (Coll. Am. Ent. Soc. and Dr. J. Gundlach, No. 444.)

Agapostemon obscurata, n. sp.

Q.-Differs from femoralis $\hat{\delta}$ only by the head and thorax being opaque black, with a more or less distinct purplish tinge, especially obvious on the face; the tip of clypeus and labrum are yellow, as in femoralis. Length $4-4 \frac{1}{2}$ lines.

Eight specimens. (Coll. Am. Ent. Soc. and Dr. J. Gundlach, No. 261). I at first supposed this to be a variety of femoralis (see Proc. Ent. Soc. Phil. iv, p. 171), but now think, with Dr. Gundlach, that it is a distinct species.

Megacilissa? nigreseens, n. sp.

ऊ.-Black; eyes large, almost meeting in the vertex, brown; cheeks, vertex and face, clothed with yellowish-white pubescence, slightly mixed with black; behind the ocelli the pubescence is black; third joint of antennæ long and slender, knobbed at the apex, sutures of remaining joints indistinctly defined, and palish beneath, the extreme tip slightly fulvous; thorax covered with a very dense, short, brown-black pubescence, a transverse band on the anterior margin, another between the wings, a stripe over the tegulæ, a mark on each side of the breast, behind the anterior femora, of whitish pubescence; metathorax with longer brown-black pubescence, and mixed with white posteriorly; tegulæ piceous; wings yellowish-hyaline, the neuration same as given by Smith (Brit. Mus. Cat. Hym. I, pl. iv, fig. 21) as that of Megacilissa; legs slender, brown, the femora reddish-brown behind, the pubescence short and pale brownish, the coxæ and base of femora with long dark pubescence, mixed with whitish ; posterior legs slender, their tibiæ slightly eurved downward; first joint of tarsi flat and as long as the remaining joints together; claws cleft; abdomen shaped much as in Apis, the first, fifth and following segments with long pubescence, that on the former mostly white, on the latter blackish; remaining segments almost nude, having a very short black pubescence, brownish when viewed in certain lights, their apical margins with a narrow fascia of pure white pubescence; venter flattened, piceous, paler at base, thinly pubescent. Length 7 lines.

One specimen. (Coll. Dr. J. Guudlach, No, 293.) 
The shape of this remarkable insect is very similar to that of Apis mellifica $\hat{\delta}$, but the oral organs, as far as can be examined, seem to refer it to Andrenidæ, and the neuration of the wings to Megacillissa, Smith.

\section{Megacillissa? subaurata, n. sp.}

o.-This is like the preceding species in shape, but differs by the pubescence of the head, thorax, legs, base and apex of abdomen and venter being yellowish-fulvous, that on face and anterior margin of thorax above being somewhat golden; that on vertex and rest of thorax above mixed with blackish, and that on the cheeks, occiput, base of abdomen and venter palest; legs pale fulvous, dusky at base, the four apical joints of tarsi fuscous; second, third and fourth abdominal segments brown-black, almost nude, and narrowly margined at tip with white pubescence; the apical margin of the first segment is slightly margined at tip with whitish. Length 7 lines.

One specimen. (Coll. Dr. J. Gundlach, No. 292.)

\section{Megachile curta.}

Megachile curta, Cresson, Proc. Ent. Soc. Phil. iv, p. 178, $\widehat{\delta}$

q.-Form short, robust; head large, transverse; thorax and abdomen short, broad; face, cheeks, pleura, and metathorax, with long, more or less dense, white pubescence; clypeus nude, sparsely punctured, apex truncate; vertex and mesothorax with short, black pubescence, the latter closely punctured except on the disk; two spots on anterior margin of mesothorax, a spot in front and another behind tegulæ, and a broad band at base of scutellum, nearly confluent with spot behind tegulæ, all of short, dense, whitish pubescence; scutellum broadly rounded; wings hyaline, dusky at tips, nervures black; legs robust, with thin hoary pubescence, more dense on tarsi; abdomen minutely and closely punctured, basal segment deeply concave in front; all the segments, except the last, with a narrow apical margin of white pubescence, that on first ending laterally in a spot; venter with long, dense, white pubescence. Length 5 lines.

Var. TIBIALIS.- $q$. Markings on thorax above yellowish, and all the tibiæ reddish.

Two specimens. (Coll. Dr. J. Gundlach, No. 109.) The variety may be a distinct species.

\section{Megachile armaticeps, n. sp.}

.- Form elongate, subparallel, opaque-black; head large, subquadrate, densely and deeply punctured, face and cheeks with long, whitish pubescence; a long hooked tooth projects from the middle of the face, 
bent downward, with obtuse tip; from each side of clypeus projects a long mandibular process, flat and carinate outwardly and subemarginate at tip, and from the middle of the elypeus projects another process, slender at base and suddenly and broadly dilated at tip, which is flattened and shaped like the letter T; mandibles large, broad at base, acute at tip; antennæ short and black; thorax densely and deeply punctured, prothorax, pleura, postscutellum and metathorax clothed with long, more or less dense, whitish pubescence; lateral margin of mesothorax extending in front of tegulæ, two spots on anterior margin, spot on disk of prothorax, and sub-interrupted line at base of scutellum, of dense, short, white pubescence; wings subhyaline, faintly clouded at apex, nervures black; legs slender, with short, thin, hoary pubescence; abdomen elongate, subquadrate, sides parallel, first and last segments densely and strongly punctured, the former deeply concave at base ; remaining segments with large deep punctures, scattered on the disk, and with a deep transverse line near base, the first five segments with a narrow apical fascia of short white pubescence, that on the first ending in a spot on each side; venter with long white pubescence. Length $5 \frac{1}{2}$ lines.

One specimen. (Coll. Dr. J. Gundlach, No. 527.)

Cœlioxys tegularis, n. sp.

o.-Elongate, black, head and thorax opaque, with large deep punctures; face, cheeks, collar, pleura, anterior and lateral margins of mesothorax, base and apex of scutellum, sides of metathorax, legs beneath, entire margin of first abdominal segment, and apical and lateral margins of remaining segments above and beneath, clothed with a short, dense white pubescence; lateral teeth of scutellum long and obtuse, tip of latter broadly rounded; tegulæ and legs fulvous; wings subhyaline, stained with yellowish fuscous; abdomen narrow, elongate, conical, shining, with deep sparse punctures; first segment broadly concave at base, apical segment opaque, minutely punctured, much depressed at tip, which is subacute, and with scattered larger punctures, the inferior plate much longer than the superior and rather broadly rounded at tip. Length $5 \frac{1}{2}$ lines.

One specimen. (Coll. Dr. J. Gundlach.)

\section{Cœlioxys producta.}

Coelioxys producta, Cresson, Proc. Ent. Soc. Phil. iv, p. 187, $\$$.

The $\delta$ is shorter and rather more robust, the head broader, the face clothed with a dense ochraceous pubescence; the second to fifth segments of abdomen have only lateral apical fasciæ; the apex is armed with six acute teeth, one on each side and four at tip (two above and 
two beneath, the latter the longer), middle of the segment deeply excavated; otherwise as in $q$. Length 5 lines.

One specimen. (Coll. Dr. J. Gundlach, No. 99.)

Melissodes mimicus, n. sp.

\$.-Black; head, thorax and base of abdomen clothed with a dense ochraceous pubescence, mixed with black on disk of mesothorax; elypeus white; antennæ as loug as body, undulate, flagellum fusco-ferruginous beneath; wings hyaline, faintly dusky at tips, nervures brown; legs piceous-black, anterior pair with ochraceous, the two posterior pair with fulvous pubescence, tips of tarsi pale fulvous; abdomen piceousblack, shining, palish at apical margin of segments, base of first segment with long, rather dense, ochraceous pubescence, a fascia of same color on disk of second, third and fourth segments, oblique and subinterrupted on second; remainder of abdomen with very short black pubescence. Length 4 lines.

Three specimens. (Coll. Am. Ent. Soc.) Smaller than Lanierii, and with pubescence of abdomen differently arranged.

\section{Exomalopsis similis.}

Exomalopsis similis, Cresson, Proc. Ent. Soc. Phil. iv, p. 191, $q$.

The $\delta$ differs from the $q$ only by the smaller size, narrower face, which is densely clothed with whitish pubescence, as well as the cheeks; the scutellum has long, erect, brown pubescence; legs clothed with whitish pubescence, mixed with brown on posterior pair; abdomen more convex. Length 3 lines.

One specimen. (Coll. Dr. J. Gundlach.)

Centris armillatus, n. sp.

\}.-Deep black; eyes large, pale; face sparsely punctured, shining ; vertex, occiput and cheeks clothed with short black pubescence; fligellum palish beneath; thorax clothed with dense short, deep black pubescence, a brcad band of yellowish-white pubescence on the anterior margin above; wings subhyaline, subviolaceous, uniformly tinged with dusky, nervures black; legs black with black pubescence, the middle femora and base of tibiæ fringed behind with long black pubescence and the posterior pair fringed on both sides with longer, dense black pubescence, forming a flattened brush; spurs of posterior tibiæ being long and curved; tarsal claws long and deeply cleft, the inner tooth much the shorter; at the base of the posterior pair a long tuft of pubescence, projecting inwardly; abdomen short convex, nude, finely punctured and shining above, the basal and apical segments and the venter with rather thin black pubescence. Length 6 lines.

One specimen. (Coll. Dr. J. Gundlach, No. 214.) 